Témoigner Témoigner. Entre histoire et mémoire

Getuigen Revue pluridisciplinaire de la Fondation Auschwitz

$119 \mid 2014$

II y a 70 ans, Auschwitz. Retour sur Primo Levi

\title{
Les frontoviki : écrivains combattants soviétiques
}

The frontoviki: soviet soldier-poets

Frontoviki: Soviet schrijvers-soldaten

Luba Jurgenson

\section{CpenEdition}

Journals

Édition électronique

URL : http://journals.openedition.org/temoigner/1485

DOI : $10.4000 /$ temoigner. 1485

ISSN : 2506-6390

Éditeur :

Éditions du Centre d'études et de documentation Mémoire d'Auschwitz, Éditions Kimé

Édition imprimée

Date de publication : 31 décembre 2014

Pagination : 173

ISBN : 978-2-84174-688-0

ISSN : 2031-4183

Référence électronique

Luba Jurgenson, «Les frontoviki : écrivains combattants soviétiques », Témoigner. Entre histoire et mémoire [En ligne], 119 | 2014, mis en ligne le 01 janvier 2016, consulté le 23 octobre 2020. URL: http://journals.openedition.org/temoigner/1485 ; DOI : https://doi.org/10.4000/temoigner.1485 


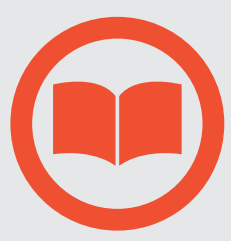

\section{MOTS DU TÉMOIGNAGE ET DE LA MÉMOIRE}

Parce que les chercheurs, les enseignants et les professionnels des arts, de la culture et de l'information sont de plus en plus amenés à utiliser des mots appartenant au champ du témoignage et de la mémoire, Témoigner entre histoire et mémoire s'est donné pour mission de les rassembler sous la forme d'un dictionnaire en ouvrant ainsi cet espace expérimental.

\section{$\rightarrow$ La réalisation de ce projet} se fait en deux temps. Chaque terme d'un index in progress est présenté en deux fois : sous la forme de notices courtes, d'abord dans chaque numéro de la revue, invitant ensuite à des développements et à une mise en débats critique, à plusieurs voix, sur un site qui fonctionnera à partir de début 2015.

À leur version courte et, donc, volontairement partielle, nous associons quelques titres d'ouvrages ne prétendant pas à l'exhaustivité.

\section{ARCHAEOLOGY OF THE HOLOCAUST}

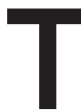
he archaeology of the Holocaust is the study of the material remains - sites and artifacts - that were associated with the persecution and mass murder of five to six million Jews by the Nazis during the Second World War. In fact, the locales of each of the hundreds of the Ghettos are potential targets for archaeological investigations, but the greatest attention is paid to the Nazi extermination centers in Poland where the archaeological research is most intensive.

The extermination centers of Chełmno, Bełżec, Sobibór and Treblinka have been, and are, subjected to archaeological research more than other sites. One of the significant results of the archaeological research is that although the Nazis levelled these sites, mostly in late 1943, remains of structures were found immediately below surface, accompanied by a profusion of artifacts from the surface and sub-surface. Mass graves have been identified in all the above sites; the exact locations of the Bełżec, Sobibór and Treblinka gas chambers have not been discovered yet. In general terms, excavations of Holocaust sites started relatively recently and the volume of the research carried out up to now remains limited, the

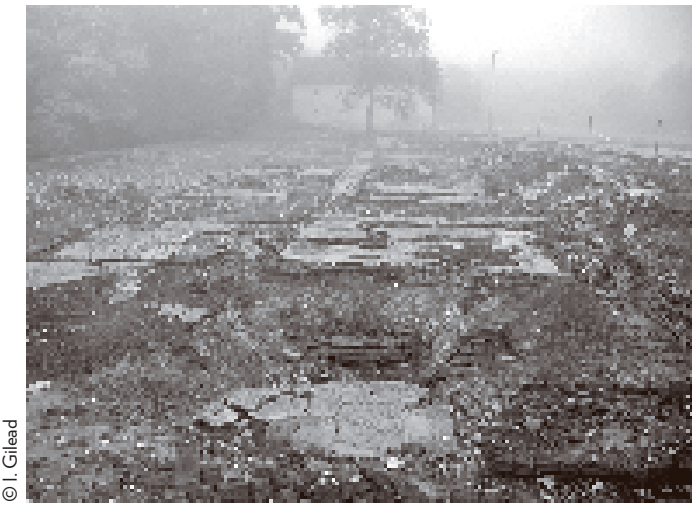

publications are rare, the results preliminary and the conclusions tentative.

One of the premises formulated by archaeologists and supported by the media is that archaeology can assert by excavations the truth of the Holocaust. However, the reality of the extermination has already been established by the historical research and local and international courts. The above premise, coupled with the pressure of the media to produce instant results in front of the cameras while in the field, is a threat to the integrity and credibility of Holocaust archaeology. More than once were archaeologists tempted to declare in the field that they stand in front of the remains of gas chambers, while the evidence they uncovered did not support such claims.

Archaeology cannot establish, or refute, the truth of the Holocaust; it can support it and illus- 
trate it with the physical evidence that was preserved and can be revealed by archaeological methods. Archaeology is important in illuminating the topography of the concentration and extermination centers, as well as in revealing the artifacts of both the victims and the perpetrators, which are essential for the teaching of the Holocaust and creating museum collections that help preserve its memory.

Isaac Gilead

Ben-Gurion University of the Negev,

Beer Sheva, Israel

\section{LES FRONTOVIKI: ÉCRIVAINS COMBATTANTS SOVIÉTIQUES}

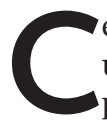

e mot désigne ceux qui ont une expérience du front, plus spécifiquement des fronts de la « Grande Guerre patriotique » (nom soviétique, puis russe de la Seconde Guerre mondiale), qu'ils aient pris part aux combats ou accompagné l'armée en tant que correspondants. Dans l'immense flot des textes qui ont pour sujet la guerre, on distingue ainsi ceux qui, indépendamment de leur forme (reportage, fiction, poésie), sont légitimés par le vécu personnel et dont les auteurs se sont exposés au danger de mort. Dès le début de la guerre, les écrivains sont mobilisés pour produire un discours fédérateur appelé à consolider l'alliance du peuple soviétique et du gouvernement face à la menace de destruction radicale. Cette alliance se fait sous le signe d'une identité russe orthodoxe ainsi qu'en témoigne le célèbre discours de Staline du 3 juillet 1941, où il ressuscite la formule « Chers frères et sœurs » s'adressant aux citoyens soviétiques comme un prêtre à ses paroissiens. La nouvelle identité vaut pour l'ensemble de l'Union conçue dans sa dimension impériale : elle forme le contexte des déportations ethniques qui s'accomplissent au même moment et annonce déjà la campagne antisémite de l'après-guerre.

La littérature aura pour tâche à la fois d'expliquer et de justifier la débâcle de la première année de la guerre, de montrer l'héroïsme des Soviétiques (inspiré par le Parti et la figure de Staline) et d'appeler à la vengeance contre les Allemands (Simonov, Ehrenbourg). Un certain nombre de tabous tenaces s'imposent, notamment sur la collaboration massive de la population des territoires occidentaux récemment annexés à l'URSS. Toutefois, le «pas en arrière » accompli par l’idéologie est perçu comme une certaine libéralisation, ce qui crée un bref espoir en une réconciliation entre le pouvoir et le peuple et en la fin des répressions. Il souffle ainsi un léger vent de liberté dans les tranchées, favorisé aussi par la violence totale à laquelle les frontoviki doivent faire face. Cela explique l'audace (relative) que se permettront certains écrivains comme Tvardovski avec son épopée Vassili Tiorkine, où le nom de Staline n'est pas mentionné, ou Nekrassov dont Dans les tranchées de Stalingrad s'écarte de la ligne officielle.

Le label de frontovik apparaît dans l'espace littéraire soviétique comme garant d'une vérité factuelle et psychologique, attestée par la condition de témoin oculaire et contrôlée en haut lieu. La littérature de la guerre sera ainsi l'occasion de perfectionner le canon imposé au témoignage écrit, envisagé d'emblée comme une construction (et toujours supervisé par un écrivain de métier), jamais comme l'expression spontanée d'une subjectivité aux prises avec le vécu. Cependant, si la plupart du temps, la « vraie guerre » est tue ou consignée dans les journaux intimes, l'épreuve de la vérité conduira certains de ces écrivains à la contestation (Tvardovski), à la dissidence (Nekrassov), voire à l'affrontement direct avec le parti (Grossman).

Luba Jurgenson EUR'ORBEM

\begin{abstract}
$\rightarrow$ Vassili Grossman, Années de guerre, Éditions en langues étrangères, Moscou, 1946 ; Vie et Destin in Fuvres, Paris, Laffont, 2006 ; Carnets de Guerre, Paris, Calmann-Lévy, 2005.

Viktor Nekrassov, Dans les tranchées de Stalingrad, Paris, Presses de la Cité, 1963.
\end{abstract}

$\rightarrow$ Alexandre Tvardovski, Vassili Tiorkine dans l'autre monde, Lausanne, l'Age d'Homme, 1990.

Constantin Simonov, Les Jours et les nuits de Stalingrad - récit d'un témoin, Paris, éd. Colbert, 1945.

\section{GEOFFREY HARTMAN}

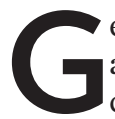

eoffrey Hartman (1929-) is a Jewish American literary critic and theorist, who has since the beginning of the 1980s made important contributions in the domains of Holocaust studies, cultural memory studies, trauma theory, as well as Jewish studies. Hartman was centrally involved in establishing what is now the Fortunoff Video Archive at Yale University in the early 1980s, and in developing it into an important initiative for the visual recording of Holocaust testimony. Much of his 
writing in the last three decades has reflected on the place of testimony in a rapidly changing media ecology. Counteracting what Hartman perceives as an excessive drive for immediacy and transparency in visual media, the video testimonies are filmed in a sober style that foregrounds the bodily presence and the voice of the witnesses and survivors. This emphasis on embodiment avoids both a tendency toward ghostliness and abstraction and the "retraumatization" of the viewers, and instead enables audiences to absorb and process historical knowledge. Hartman's double concern for the precariousness of historical transmission and for the vital importance of artistic and literary form can be understood in light of his long career as a leading critic of romantic literature, and especially of the work of William Wordsworth. Hartman encountered Wordsworth's poetry when a Kindertransport brought him from Germany, his native country, to the English countryside and allowed him to escape the Holocaust. After moving on to the States, Hartman was educated at Yale, where he later taught for more than four decades. In the 1970s and 1980s, he was associated with the rise of deconstruction, a literary critical approach that foregrounds the limits of textual understanding and the instability of linguistic constructs. For Hartman, deconstruction nourished his interest in teasing out unexpected and oblique meanings and resonances in literary texts (an approach he also connected to the Judaic interpretive tradition of midrash). The patient attention to the unobtrusive undertones of language and to elements that resist fore- grounding persists in Hartman's work on Holocaust testimonies, as well as in his influential writings on trauma. Whether dealing with literary texts, Holocaust testimonies, or traumatic discourse more generally, Hartman's practice is one of carefully "reading the wound" rather than sealing it.

Pieter Vermeulen University of Leuven

\section{BARTOLOMÉ DE LAS CASAS}

B artolomé de Las Casas (14741566) a consacré sa vie à défendre les Indiens d'Amérique dont les Espagnols avaient entrepris de conquérir les terres, et de convertir depuis la découverte du continent par Christophe Colomb en 1492. Parti au Nouveau Monde en 1502 au tout début de la Conquête, le colon Las Casas connut une véritable conversion en écoutant le sermon du dominicain Antonio de Montesinos, prononcé un dimanche de l'Avent de l'année 1511 sur l'île Hispaniola (actuelle République Dominicaine). Montesinos dénonçait avec force les modalités d'exploitation de la population indigène qui, sous le coup redoublé des attaques microbiennes et des exactions des espagnols, connaissait un effondrement démographique terrifiant. Devenu dominicain, Las Casas n'eut de cesse de combattre les fondements idéologiques de la colonisation et ses modalités pratiques, dénonçant sans relâche l'iniquité du système de la Encomienda, qui, de fait, permettait l'asservissement des Indiens. Témoin essentiel des cinquante premières années de la Conquête, Las Casas fut un acteur fondamental du débat théorique, théologique et politique qui animait l'Espagne de cette époque autour des questions liées à la Conquête, à la Guerre juste, à l'exercice légitime du pouvoir et à l'évangélisation. Sous l'influence du dominicain, Charles Quint promulgua en 1542 un nouveau corpus législatif. Ces Lois Nouvelles abolissaient la Encomienda et furent à l'origine de violentes révoltes notamment dans la toute jeune vice-royauté du Pérou, obligeant l'empereur à transiger. Soucieux d'établir la légitimité des droits de l'Espagne à gouverner l'Amérique, Charles Quint convoqua une réunion (la bien connue Controverse de Valladolid [1550-1551]) au cours de laquelle Las Casas, alors nommé évêque de Chiapas en 1543, s'opposa violemment à Juan Ginés de Sepúlveda, humaniste éminent, partisan de la théorie de l'esclavage par nature fondée sur des principes aristotéliciens et appliquée aux Indiens d'Amérique. Ces activités d'homme de terrain et de penseur politique engagé s'appuyaient sur des écrits. Le plus célèbre d'entre eux reste sans conteste la Très brève relation de la destruction des Indes (1552) dans lequel Las Casas énumérait les horreurs de la Conquête montrant qu'elle avait abouti à la négation de l'autre et à son anéantissement. Cette œuvre polémique, à la dimension prophétique, n’est pas isolée dans la production de las Casas qui comprend d'autres œuvres de combat, comme l'Histoire des Indes et l'Histoire Apologétique des Indes dont le but était de construire et de défendre la mémoire et l'histoire des Indiens d'Amérique. Las Casas y démontrait la totale rationalité des populations indigènes et affirmait avec force l'unicité de la race humaine. 
Penseur complexe, ne reculant pas devant la polémique, homme de foi, combattant acharné, Las Casas devint pour l'histoire collective l'un des premiers défenseurs des droits de l'homme.

Nejma Kermele

Université de Pau et des Pays de l'Adour

$\rightarrow$ Marcel Bataillon, Études sur Bartolomé de Las Casas, Paris, Centre de recherches de l'Institut d'Etudes Hispaniques, 1966.

Bernard Lavallé, Bartolomé de Las Casas, entre l'épée et la Croix, Payot, Paris, 2007.

\section{MEMORY AND THE} ANTHROPOCENE

$\mathrm{T}$ he increase in carbon-dioxide emissions through the burning of fossil fuels and its effects of global warming has left a geological record, as shown by polar ice core samples that date from the mid-to-late-eighteenth century. This has prompted Paul J. Crutzen and Eugene F. Stoermer (in 2000 and 2002) to identify the end of the previous geological epoch, the Holocene, the warmer period of 10-12 millennia that succeeded the ice age of the Pleistocene. Crutzen and Stoermer have identified the Anthropocene, as succeeding the Holocene, to designate a new era of anthropogenic climate change, the geological evidence for which dates back to James Watts' invention of the steam engine in 1784.

How might the study of the cultural memory be recalibrated in the era of critical change? Current theories of mourning may prove inappropriate, as their logic suggests that that which is lost can be renewed by a repudiation of libidinal attachments to the lost object and reattachment to its replacement. Put otherwise, the loss, depletion and degradation of environments, ecologies, resources, species and ways of life would be deemed sustainable, and that which has been lost forgettable: an economy of mourning that could be disrupted by an ecomelancholic stance (James 2001).

Given the multiscalar dynamics of climate change and environmental degradation that are unfolding across time and space, life and matter in predictable, unpredictable and mutating ways, memory studies should also refrain from delimiting that which is to be remembered as a discrete and static object. Given the imbrication of human and non-human worlds and systems described by the Anthropocene, memory studies need to adopt a posthumanist stance, otherwise it will be circumscribed by the normative theorization of memory's symbolic reconstitution of human life and human worlds (Cohen 2012).

Furthermore, that the Anthropocene can be dated back to the beginnings of the industrial revolution should not limit the temporal horizons of memory studies. While the Anthropocene has been caused by the advent of industrial capitalism, its globalization and its legacies, and while the catastrophic effects of the Anthropocene are accentuated by global capitalism's distribution of social inequality, a deeper sense of geological time will identify the conditions under which life becomes precarious and indeed impossible, in the past, present and in the future. As Dipesh Chakarbarty (2009) puts it, the current geological era calls for thinking species history alongside a critique of capitalism.

The difficulties of predicting where, when and to what degree environmental damage will manifest itself in systemic ways (across global systems) and through cumulative, local degradation calls for a radically enlarged spatial scale of cognition, as does the idea of causality in the Anthropocene in which human actions lend agency to non-human materials and systems that effect differentiated change across the planet. By temporalizing and spatializing its objects of remembrance through a "derangement of scale" (Clark 2012), memory studies is better positioned to remember the Anthropocene.

\section{Richard Crownshaw Goldsmiths University of London}

$\rightarrow$ Chakrabarty, Dipesh, 'The Climate of History: Four Theses', Critical Inquiry 35 (2), 2009, 197-222.

$\diamond$ Clark, Timothy, 'Scale: Derangements of Scale', in Tom Cohen (ed.), Telemorphosis: Theory in the Era of Climate Change, Vol. 1., Open Humanities Press/University of Michigan Library, 2012, 148-166.

Cohen, Tom, 'Introduction: Murmurations - "Climate Change" and the Defacement of Theory', in Id. (ed.), Telemorphosis: Theory in the Era of Climate Change, Vol. 1, Open Humanities Press, 2012, 13-42.

$\Leftrightarrow$ James, Jennifer C., 'Ecomelancholia: Slavery, War, and Black Ecological Imaginings', in Stephanie LeMenager, Teresa Shewry \& Ken Hiltner (eds.), Environmental Criticism for the Twenty-First Century, London: Routledge, 2011. 


\section{MULTIDIRECTIONAL} MEMORY

$\mathbf{T}$ he term "multidirectional memory" was coined as a way of conceptualizing what happens when different histories of extreme violence confront each other in the public sphere. While acknowledging the struggles and contestations that accompany public articulations of memory, the theory of multidirectional memory seeks an explanation of the dynamics of remembrance that does not simply reproduce the terms of partisan groups involved in those struggles. I have developed this theory at greatest length in my book Multidirectional Memory: Remembering the Holocaust in the Age of Decolonization (2009), which focuses on exemplary sites of tension involving remembrance of the Nazi genocide of European Jews in relation to slavery, colonialism, and decolonization.

In Multidirectional Memory, I offer a new framework for thinking about memory contestation via three core arguments. First, I argue against what I call "competitive memory," an understanding that is based on the logic of the zero-sum game and has dominated many popular and scholarly approaches to public remembrance. According to this understanding, memories crowd each other out of the public sphere-for example, too much emphasis on the Holocaust is said to marginalize other traumas or, inversely, adoption of Holocaust rhetoric to speak of those other traumas is said to relativize or even deny the Holocaust's uniqueness. In contrast, I suggest, memory works productively through negotiation, cross-referencing, and borrowing; the result of memory conflict is not less memory, but more-even of subordinated memory traditions.

In illustrating this nonzero-sum logic, I take a second step already implied by an understanding of memory's productivity: I argue that collective memories of seemingly distinct histories are not easily separable from each other, but emerge dialogically. For example, not only has memory of the Holocaust served as a vehicle through which other histories of suffering have been articulated, but the emergence of Holocaust memory itself was from the start inflected by histories of slavery, colonialism, and decolonization that at first glance might seem to have little to do with it.

Finally, the theory of multidirectional memory casts doubt on the taken for granted link between collective memory and group identity that has been at the core of memory studies-the direct line that seems to bind, for example, Jewish memory and Jewish identity and to differentiate them clearly from African American memory and African American identity. Multidirectional Memory demonstrates, however, that the borders of memory and identity are jagged (see also Landsberg, Silverman, Sanyal). Groups do not simply articulate established positions but come into being through dialogical acts of remembrance that take place on a shared, but uneven terrain. The shared terrain of multidirectional memory creates possibilities for unexpected forms of solidarity, but it offers no guarantees.

Michael Rothberg University of Illinois $\diamond$ Landsberg, Alison, Prosthetic Memory: The Transformation of American Remembrance in the Age of Mass Culture, New York: Columbia UP, 2004.

$\diamond$ Rothberg, Michael, Multidirectional Memory: Remembering the Holocaust in the Age of Decolonization, Stanford: Stanford UP, 2009.

Sanyal, Debarati, Memory and Complicity: Migrations of Holocaust Remembrance, New York: Fordham UP, forthcoming.

Silverman, Max, Palimpsestic Memory: The Holocaust and Colonialism in French and Francophone Fiction and Film, New York: Berghahn, 2013.

\section{SEPTEMBER 11, 2001}

$\mathrm{D}$ espite suggestions that the post-9/11 era would mark the end of the "memory boom" (Klein 2000) that preoccupied critical and cultural discourses at the end of the twentieth-century (Zehfuss 2003), in the aftermath of 11 September 2001, discussions about commemoration occupied the forefront of public consciousness in the United States, as debates over the redevelopment of Ground Zero, the widespread consumption of commemorative memorabilia, and ongoing controversies over the ways in which the deaths of $9 / 11$ victims were mobilized in support of the War on Terror, impelled unprecedented attention to the politics and ethics of memory.

Despite the diversity of perspectives embraced by commemorative media relating to $9 / 11$, the culture of memory surrounding the attacks has arguably been most notable for the ways in which the institutions of the American 


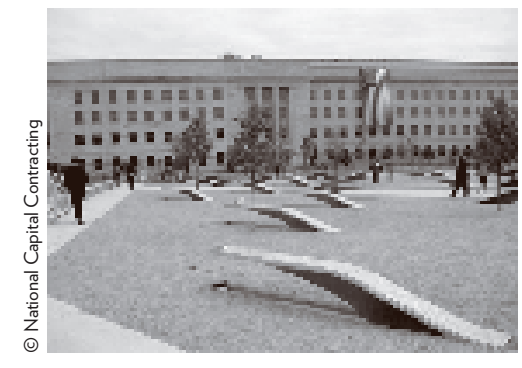

public-political sphere have sought to nationalize the trauma of September 11. In the immediate aftermath of the attacks, President George W. Bush declared 9/11 a "national tragedy"; in December 2001, Bush designated 11 September as Patriot Day; in 2005, the True American Heroes Act of 9/11 designated a commemorative medal to "all government workers and others who responded to the attacks on the World Trade Center and the Pentagon"; and in November 2011, the Fallen Heroes of 9/11 Act awarded Presidential medals to the three memorials erected at the site of the attacks - the National September 11 Memorial in New York (designed by Michael Arad and Peter Walker), the Flight 93 National Memorial in Shanksville, Pennsylvania (designed by Paul Murdoch Architects), and the Pentagon Memorial (designed by Julie Beckman and Keith Kaseman).

As a number of commentators have noted (Sturken 2007), such endeavours facilitated the emergence of a politicized and exclusionary culture of memory that appeared to privilege American lives over others, most notably the Iraqi and Afghan deaths designated as "collateral damage" in the War on Terror. Resistant to the development of such "hierarchies of life" (Butler 2004), critics (Rothberg 2009a; Gray 2011) have subsequently argued for a recalibration of memorial culture to engender a global dialogue about the attacks and their aftermath. Construing memory as comparative and not competitive, such discourses resonate strongly with the recent "transcultural turn" in memory studies (Bond \& Rapson 2014), pioneered by theorists such as Daniel Levy and Natan Sznaider (2006), Michael Rothberg (2009b), and Astrid Erll (2011).

\section{Lucy Bond \\ University of Westminster}

Bond, Lucy \& Jessica Rapson (eds.), The Transcultural Turn: Interrogating Memory Between and Beyond Borders, Berlin: Walter de Gruyter, 2014.

$\diamond$ Butler, Judith, Precarious Life: The Powers of Mourning and Violence, London: Verso, 2004.

$\diamond$ Erll, Astrid, 'Travelling Memory', Parallax 17(4), 2011, 4-18.

Gray, Richard, After the Fall: American Literature Since 9/11, Oxford: Wiley-Blackwell, 2011.

$\rightarrow$ Klein, Kerwin Lee, 'On The Emergence of "Memory" in Historical Discourse', Representations 69 (4), 2000, 127-150.

$\diamond$ Levy, Daniel \& Natan Sznaider, The Holocaust and Memory in the Global Age, translated by Assenka Oksiloff, Philadelphia: Temple University Press, 2006.

$\diamond$ Rosenfeld, Gavriel D., A Looming Crash or a Soft Landing? Forecasting the Future of the Memory "Industry", Journal of Modern History 81(1), 2009, 122-158.

Rothberg, Michael, A Failure of the Imagination: Diagnosing the Post-9/11 Novel: A Response to Richard Gray', American Literary History 21(1), 2009a,152-58.

$\diamond$ Sturken, Marita, Tourists of History, Durham and London: Duke University Press, 2007.

$\rightarrow$ Zehfuss, Maja, 'Forget September 11', Third World Quarterly 24(3), 2003, 513-528.

\section{TOURISM AND MEMORY}

$\square$ xperience of place significantly informs where the past is understood in the present day. When Maurice Halbwachs introduced the notion of collective memory (1925), he noted the way in which social groups are constantly involved in a process of "implacement"; collectives are partly constituted by collaborative experiences of place, thus rendering it a key component of collective memory. Landscapes are frequently perceived to function as archives of human history and experience; this perhaps explains the "pull" of sites of memory, for the act of physical travel can be seen to stand in for something we cannot do: to travel back into the past itself.

Memory tourism has been of increasing interest to scholars across the social sciences and humanities, producing comprehensive work on the role heritage institutions and commemorative landscapes play in mediating processes of individual and collective memory and identity (Samuel 1994). Considerable scholarship on "Dark Tourism" (Foley \& Lennon 2000) examines visits to sites of death, suffering, disaster and violence (although not all types of "dark tourism" or associated scholarship directly concerns either memory or commemoration) and has produced detailed typologies of "dark tourism" practices. Other terms employed include "thanatourism" (Seaton 1996), which places a more explicit focus on the contemplation of death. Contributions from disciplines beyond tourism studies, including anthropology and cultural studies 
(MacDonald 2008), literary criticism and travel writing (Jones 2007), social and cultural geography (Charlesworth \& Addis 2002) and historiography (Gilbert 1999) provide alternative perspectives.

There is considerable diversity within this field, although tourism to sites related to the Nazi Holocaust has arguably received the most substantial attention (in line with much other work on memory and commemoration in recent decades). Tourism to post-genocide Cambodia and Rwanda are also the subject of increasing scrutiny, and albeit to a lesser extent, to former Yugoslavia and Armenia. However, substantial works on sites of internment, suffering or injustice in, for example, Latin America, South Africa and Northern Ireland, have also appeared in recent years, as have contributions on battlefield and war tourism and sites of nuclear disaster and terrorism. Issues discussed - both in "dark tourism" scholarship and on memory and tourism more generally - include visitor motivation and experiences of "authenticity", and the potential moral and pedagogical value of particular sites.

Jessica Rapson King's College London

Foley, M. \& J. J. Lennon, Dark Tourism: The Attraction of Death and Disaster, New York \& London:

Continuum, 2000.

$\rightarrow$ Gilbert, M., Holocaust Journey: Traveling in Search of the Past, New York: Columbia University Press, 1999.

$\rightarrow$ Jones, K., Journeys of Remembrance: Memories of the 2nd World War in French and German Literature, 1960-1980, London \& Leeds: Legenda, 2007.

MacDonald, S., Difficult Heritage: Negotiating the Nazi Past in
Nuremberg and Beyond, London and New York: Routledge, 2009.

Samuel, R., Theatres of Memory: Past and Present in Contemporary Culture, London: Verso, 1994.

Seaton, A.V., 'Guided by the dark: From thanatopsis to thanatourism', International Journal of Heritage Studies 2(4), 1996, 234-244.

\section{TRANSCULTURAL MEMORY}

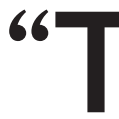
ranscultural memory" emerged in or around 2010 within the field of memory studies. The "transcultural turn” (Bond \& Rapson 2014) describes the programmatic move away from the assumption that memory is the product of bounded "cultures", often national cultures at that - an idea which had crept into a large section of memory research, especially in the wake of Pierre Nora's lieux de mémoire. Proponents of transcultural memory studies criticize such "methodological culturalism”. They emphasize instead the fluidity and fuzziness of memory in culture as well as the non-isomorphy of culture, nation, territory, ethnicity, social groups, and memory (see the articles in Parallax 17 (4), 2011, ed. Crownshaw). As a theory and methodology, transcultural memory means a change in the focus attention: from stable and allegedly "pure" national-cultural memory towards the movements, connections, and mixing of memories.

In our globalizing age, archives and repertoires of memory have increasingly become interlinked, the prominent example being the ways in which Holocaust memory has travelled virtually across the globe and was turned into a language that enabled people to address histories of extreme violence and the violation of human rights. Scholars have studied such a dynamics as "memory in the global age” (Levy \& Sznaider 2006) and as "multidirectional memory” (Rothberg 2009). However, "transcultural memory" does not only refer to (1) such deliberate and productive connections ofmemories that were formerly considered as distinct and belonging to different groups; it can more generally be conceived of as (2) the movement of mnemonic archives across spatial, temporal, and social, but also linguistic and medial borders (Erll 2011) as well as (3) the mixing of memories in contexts of high cultural complexity. Memory is fundamentally transcultural. No version of the past and no product in the archive will ever belong to just one community or place, but usually has its own history of "travel and translation". This is not only the case in our present age of globalization, but as mnemohistory has shown, this holds also true in a longue durée-perspective on memory.

\section{Astrid Erll \\ Goethe Universität Frankfurt}

Bond, Lucy \& Jessica Rapson (eds.), The Transcultural Turn: Interrogating Memory between and beyond Borders, Berlin/New York: de Gruyter, 2014.

Crownshaw, Richard, Transcultural Memory, Special Issue Parallax 17 (4), 2011.

$\diamond$ Erll, Astrid, 'Travelling Memory', Parallax 17 (4), 2011, 4-18.

$\rightarrow$ Levy, Daniel \& Natan Sznaider, The Holocaust and Memory in the Global Age, Philadelphia: Temple UP, 2006.

$\diamond$ Rothberg, Michael, Multidirectional Memory: Remembering the Holocaust in the Age of Decolonization, Stanford: Stanford UP, 2009. 


\section{Site mémoriel}

\section{DIXMUDE}

La

Passerelle de l'Espoir. mande. Mais la métamorphose ne concerne pas seulement les étages de la Tour de l'Yser abritant le musée ; le site entier a été remanié, y compris le parking et le pavillon d'accueil à côté de la Porte de la Paix. Une imposante allée, qui contient les noms des villes martyres belges, Nieuport et Dixmude formant la clé de voûte, mène aujourd'hui les visiteurs jusqu'au pied de la Tour. Moins d'un an après sa réouverture, le musée se révèle être un grand succès auprès du public: le 17 septembre, il a accueilli son $100000^{\mathrm{e}}$ visiteur.

\section{" QUE RESTE-T-IL DE LA VIE ? "}

Le musée s'articule sur 22 étages thématiques, proposant un trajectoire qui conduit du sommet de la tour au rezde-chaussée et s'inspire de la devise : "Que reste-t-il de la vie ? Que restet-il du pays? » La « vie » renvoie ici à l'expérience des soldats, notamment pendant la guerre et dans les tranchées, plutôt qu'à la vie de la population dans les zones occupées ou au retour à la vie après le cataclysme. C'est l'histoire militaire de la Grande Guerre qu'on nous propose à Dixmude.

S'appuyant sur une scénographie particulière, le musée s'applique en outre à rendre les expériences des soldats en 14-18 les nôtres. Avant même d'entrer dans la tour, nous empruntons la « Passerelle de l'Espoir», un pont en bois utilisé à l'époque par les fantassins pour joindre les avant-postes. L’idée de cette « reconstruction véridique », ••• 

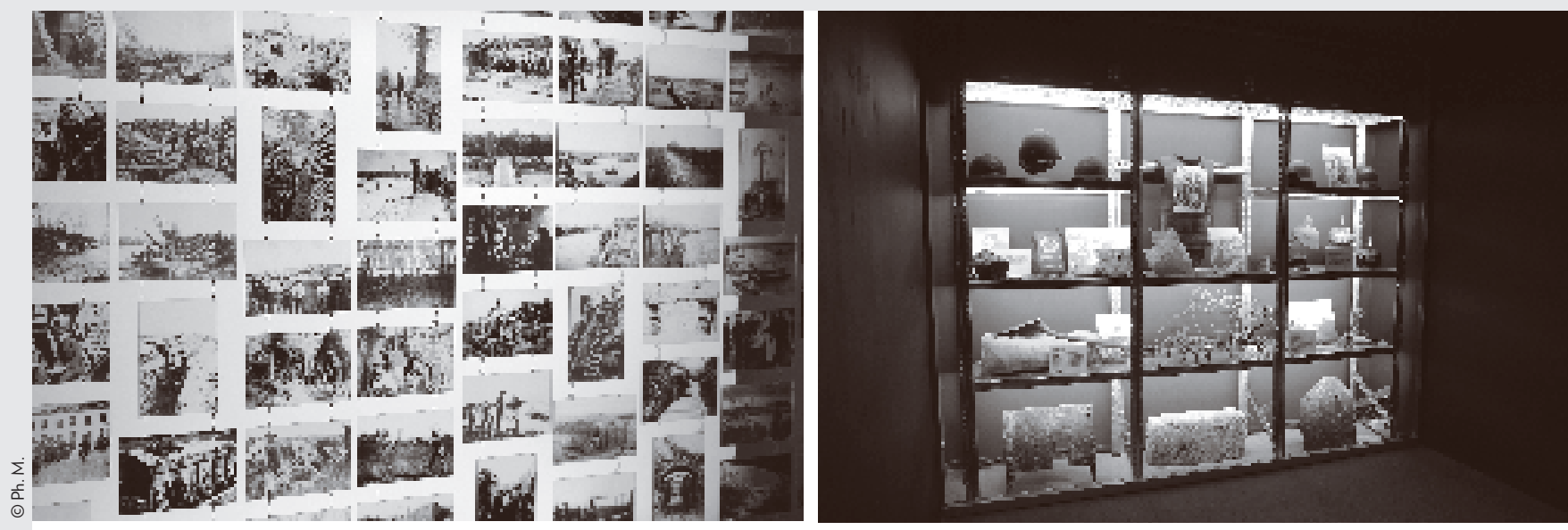

\begin{abstract}
४ $16^{\mathrm{e}}$ étage "À l’Yser ». $\rightarrow 14^{\mathrm{e}}$ étage "L'homme vs. la machine ». $\checkmark 13^{e}$ étage "L'homme vs. la machine ».
\end{abstract}

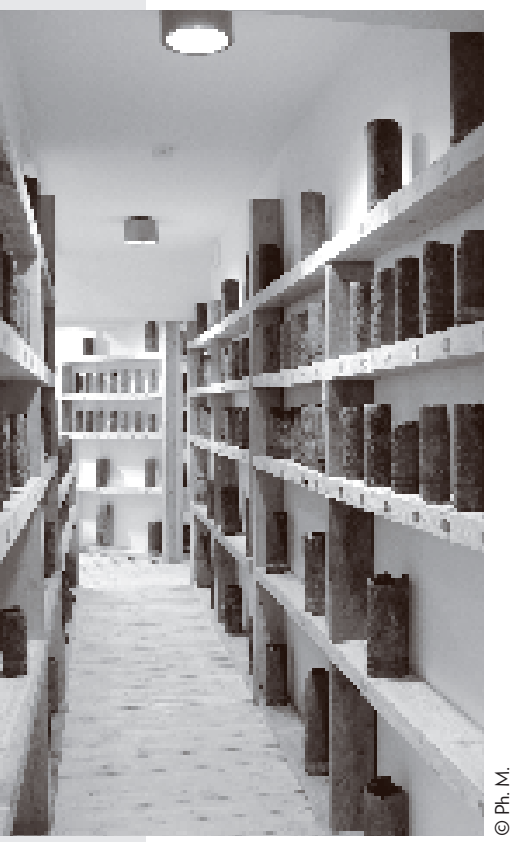

•• selon le site du musée, serait bien de «donner au visiteur le sentiment de traverser une zone immergée pendant la Première Guerre mondiale ». Cette scénographie conçue pour que la visite soit une véritable expérience suit ce même principe dans le musée. Au $15^{\mathrm{e}}$ étage, le visiteur se retrouve dans un labyrinthe où il cherche son chemin à tâtons dans la pénombre. Comme $s$ 'il se promenait dans une tranchée, le plancher craque sous ses pieds, la respiration haletante d'un soldat en agonie est transmise avec insistance par une bande sonore. Là encore, l'installation invitant à l'identification et à l'empathie, nous sommes transformés en témoins de substitution (vicarious witnesses) appelés à se mettre à la place de ce soldat dont la photo apparaît dans un coin du labyrinthe. Le Musée le long de l'Yser vise clairement, à travers ces simulations, à impliquer le visiteur à un niveau émotionnel et physique, et à lui faire revivre l'expérience de la Grande Guerre. Même si cette stratégie est récurrente dans le contexte des pédagogies mémorielles actuelles, l'on pourrait se demander, à l'instar de Marianne Hirsch, s'il n'est pas possible d'imaginer d'autres formes de solidarité entre ceux qui ont vécu la guerre et ceux qui la commémorent.

En revanche, ailleurs dans le musée, on a opté pour un dispositif dépouillé et minimaliste qui crée une certaine distance. C'est le cas au $16^{\mathrm{e}}$ étage où la vie dans les tranchées est illustrée à l'aide de photos en sépia et en noir et blanc, suspendues devant des écrans lumineux. Le $14^{\mathrm{e}}$ étage, consacré à la lutte entre «l'homme et la machine », frappe également par sa scénographie austère : dans une série de vitrines, on expose des objets caractéristiques de la guerre moderne et industrialisée. En descendant, nous découvrons des étagères longues de plusieurs mètres sur lesquelles des centaines d'obus sont présentés comme des urnes, chacun portant le nom d'un soldat mort pendant la guerre. Ce type d'espace fait contraste avec le $9^{\mathrm{e}}$ étage où l'artiste flamand Peter Jacquemyn a couvert les murs et les plafonds blancs d'une gigantesque fresque murale au fusain. C'est une représentation macabre et oppressante du champ de bataille où les cadavres enterrés à la hâte refont surface, éventrés et déchirés, les os retenus par les seules bottes des militaires (Knochenhalter). 
"QUE RESTE-T-IL DU PAYS ? "

«Que reste-t-il de la vie? Que restet-il du pays?» Le deuxième volet de l'exposition concerne le front du Westhoek, la plaine de l'Yser qui a tellement souffert sous la Première Guerre mondiale. La terrasse panoramique de la tour à Dixmude, un peu à l'instar du beffroi d'Ypres qui depuis 2012 fait partie du parcours muséal In Flanders Fields, offre une vue imprenable sur la région et permet au visiteur de détecter les cicatrices que la guerre a laissées dans le paysage. Un paysage qui se lit dès lors comme un palimpseste : certaines cicatrices restent très visibles aujourd'hui, telles que les cratères creusés par la guerre souterraine entre Britanniques et Allemands en 1917 ou les nombreux cimetières et monuments qui nous rappellent les événements tragiques qui s’y sont déroulés il y a un siècle.

Le musée met en évidence l'impact de la guerre sur la terre - et de la terre sur la guerre. Le visiteur qui descend de la terrasse au $22^{\mathrm{e}}$ étage retrouve un grand tableau suspendu au plafond qui représente la région de Dixmude à l'époque de l'inondation : quand les portes des écluses à Nieuport s'ouvrent le 28 octobre 1914, le champ de bataille se transforme en bourbier et la guerre de mouvement s'enlise dans une guerre de positions. Les photos sépia et noir et blanc montrent les soldats dans les tranchées et aux avant-postes, affairés à construire des passerelles et des tunnels, ou s'efforçant à mener une vie « normale » malgré les circonstances : ils se baignent dans les territoires inondés, élèvent des poissons ou cultivent des pommes de terre. Le rapport entre guerre et environnement est analysé ensuite aux $2^{\mathrm{e}}$ et $3^{\mathrm{e}}$ étages où l'on a partiellement reconstruit «Beecham Dugout » (encore cette idée de faire revivre au visiteur l'expérience de la guerre), un abri souterrain britannique appartenant à un réseau de tunnels de plus de 4500 kilomètres en Flandre occidentale.

Le pays donc, la terre, la boue, les Vlaamse Velden, le paysage, les cratères, mais aussi : l'identité nationale. «Que reste-t-il de la Belgique après la guerre? » Il n'est pas tout à fait surprenant, bien sûr, de découvrir à Dixmude l'histoire du Mouvement flamand et de ••• $\checkmark 9^{\mathrm{e}}$ étage «Knochenhalter».

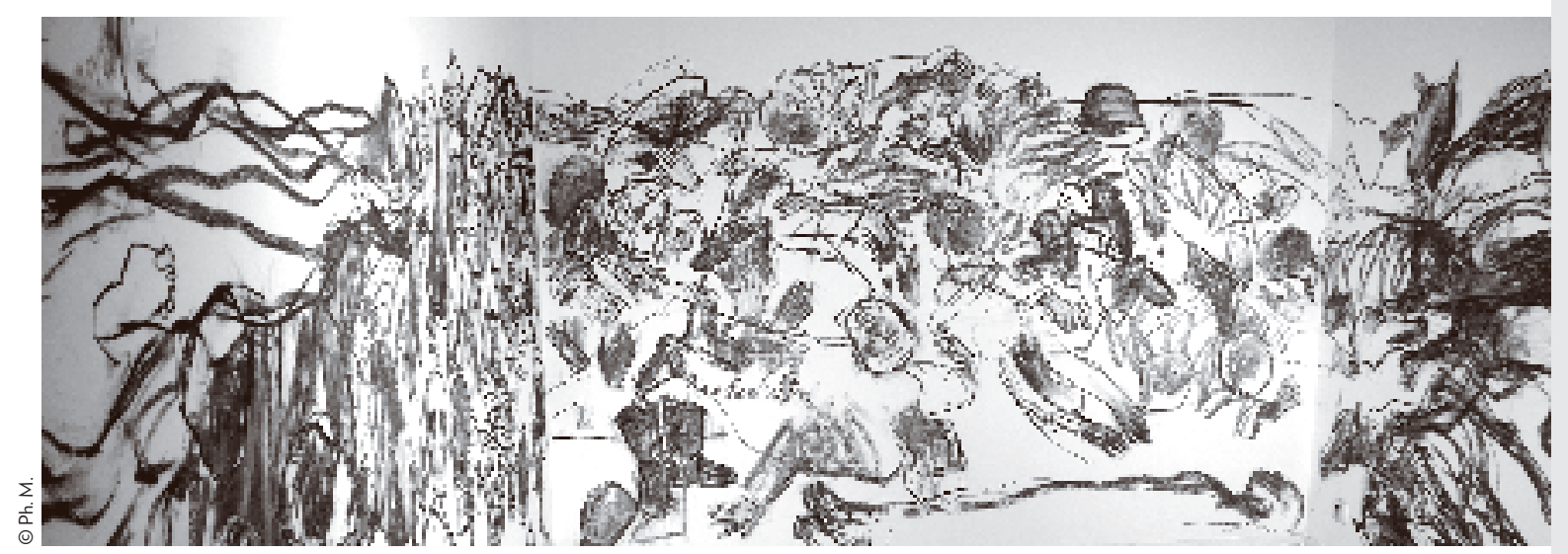




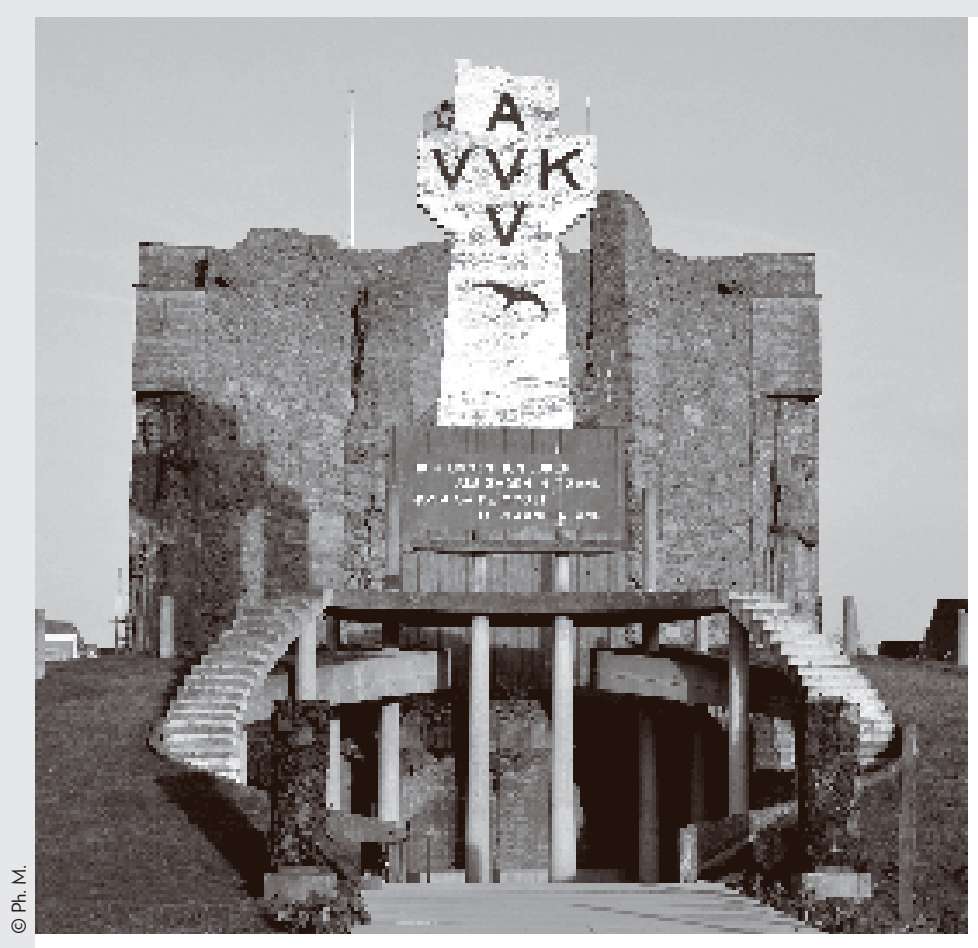

Porte de la Paix et crypte.
• la Tour de l'Yser elle-même, qui se présente comme un tombeau géant pour les soldats flamands. Dès son entrée sur le site, le visiteur est immergé dans la symbolique nationaliste-flamande. En passant par la Porte de la Paix contenant les lettres croisées AVV-VVK («Alles voor Vlaanderen - Vlaanderen voor Kristus », « Tout pour la Flandre, la Flandre pour le Christ ») et la mouette volante (blauwvoet, d'après la formule d'Albrecht Rodenbach), il traverse une crypte érigée sur les ruines de la première Tour de l'Yser, dynamitée en 1946 mais qui renaît glorieusement de ses cendres en 1965. Un poème de Cyriel Verschaeve attire l'attention («Hier liggen hun lijken als zaden in 't zand - hoop op de oogst, O Vlaanderland », « Ici reposent leurs corps comme des graines dans le sable - aie foi en la moisson Ô Flandre ») ainsi que l'inscription sur la « Pierre de Merkem » («Hier ons bloed, wanneer ons recht », « Voici notre sang, quand aurons-nous nos droits », référence à la lutte linguistique et d'émancipation). Dans la crypte reposent les «Symboles de l'Yser », neufs jeunes hommes morts pendant la Première Guerre mondiale qui représentent le combat des soldats flamands - le combat pour la Flandre. Ensuite, au premier étage de la tour même, on a installé La Toile d'Or de la Flandre, le tableau de Hendrik Luyten réunissant dans une scène symbolique les sommités du Mouvement flamand et notamment les activistes. Enfin, sur le toit de la Tour flotte à nouveau le drapeau du lion, après que le remplacement de celui-ci par le drapeau du musée au printemps a provoqué un tollé parmi les nationalistes flamands.

Le parcours muséal présente l'histoire de la Grande Guerre de ses débuts (le militarisme et les alliances), en passant par la confrontation belgo-allemande jusqu’à son dénouement (téléo) logique : la naissance du Frontbeweging et la consolidation du Mouvement flamand. Le motif de « l'identité nationale » sert en outre de fil rouge et de question, à travers le musée entier. À plusieurs endroits, le visiteur est invité à ouvrir des « Fenêtres », des panneaux sous forme de drapeau national qui se présentent comme autant de moments de réflexion sur la question de l'identité. Néanmoins, cette question ne cesse d'être ramenée à l'idée de la nation, une nation dotée de ses propres symboles, ses rituels, ses héros, son histoire. On regrette le peu d'espace réservé à des visions alternatives sur l'identité - en tant que construction culturelle et sociale, imaginée mais bien réelle ou sur la mémoire, transnationale et 
transculturelle au lieu d'être rivée aux frontières nationales (qu'elle soient flamandes ou belges) et mobilisée à des fins politiques.

\section{PAIX - LIBERTÉ - TOLÉRANCE}

Le musée s'est donné comme mission de promouvoir le triple message Paix-Liberté-Tolérance, une relecture du slogan «Plus jamais de guerre » présent en quatre langues sur les murs de la Tour de l'Yser. L’idée de la paix s'insinue en effet partout dans le site : elle inspire les œuvres conçues par l'artiste ouest-flamand Willem Vermandere près de la crypte, puis le film « La violence n'apporte jamais la paix » projeté en permanence dans le hall d'entrée du musée. Il est alors étonnant de retrouver, dans ce même hall, une série de panneaux listant les conflits des cent dernières années, de l'Insurrection de Pâques en Irlande en 1916 à la Seconde Guerre mondiale, la Shoah et les crises actuelles en Syrie, au Gaza, en Irak et en Ukraine. Les panneaux portent toutefois le message « Plus jamais de guerre».

Faut-il voir là une sorte d'acte manqué involontairement cynique? De la naïveté ? Une sorte d'idéalisme ? Le musée semble mettre en question son propre message de pacifisme radical, qui s'annule inévitablement dans la confrontation aux violences et aux souffrances perpétuelles. Notons que ce paradoxe est également présent à la fin de l'exposition du musée In Flanders Fields à Ypres qui expose une série analogue de conflits mettant en évidence que la Grande Guerre marque plutôt le début d'un cycle de violences de plus en plus meurtrières, qu'une leçon pour ne pas aller plus loin dans la destruction. De toute façon, à force de chanter «Plus jamais de guerre », on évite de poser les questions essentielles que cette liste évoque : pourquoi l'homme continue-t-il à faire la guerre ? Quels sont les mécanismes de base qui font déclencher les conflits? Comment en étudier tant les dimensions locales qu'internationales? Mais aussi, comme se le propose le Musée de Dixmude mais en se limitant au cas du soldat (flamand) au front : comment les hommes et les femmes vivent-ils la guerre? Il faudrait également se demander quelles sont les incidences de l'ultranationalisme, du séparatisme identitaire ou communautariste, sur le déclenchement ou l'amplification des conflits. Comment, très concrètement, la violence engendre-telle la violence?

Force est de constater ici la faillite du discours nationaliste à saisir la réalité complexe de la guerre. L'attention portée à la Flandre (le « pays ») et à la misère du soldat flamand dans les tranchées (la « vie »), aussi logique que cela puisse paraître pour un musée situé dans un haut-lieu du mouvement nationaliste, semble bien interférer à une analyse plus approfondie du phénomène de la guerre. La symbolique ferait ainsi obstacle à une approche sociale et psychologique de cette explosion de violence qu’a été la Première Guerre mondiale.

\section{Anneleen Spiessens}

Richard Crownshaw, Transcultural Memory, Special Issue Parallax 17 (4), 2011.

$\rightarrow$ Chiara De Cesari et Ann Rigney (dir.), Transnational Memory : Circulation, Articulation, Scales. Berlin et New York, de Gruyter, 2014.

Astrid Erll et Ann Rigney (dir.), Mediation, Remediation, and the Dynamics of Cultural Memory, Berlin et New York, de Gruyter, 2009.

$\rightarrow$ Marianne Hirsch, The Generation of Postmemory : Visual Culture After the Holocaust, New York, Columbia University Press, 2012. 